\title{
Keefektifan Model Problem Based Learning(PBL) Berbantuan Tangram terhadap Hasil Belajar Matematika Kelas IV
}

\author{
Trimurtini $^{*}$, Nur Laela ${ }^{2}$ \\ ${ }^{1,2}$ Universitas Negeri Semarang \\ "trimurtinipgsd@mail.unnes.ac.id
}

Diterima: Mei 2020. Disetujui: Juli 2020. Dipublikasikan: Juli 2020.

\begin{abstract}
ABSTRAK
Berdasarkan hasil observasi dan wawancara hasil belajar kognitif matematika siswa kelas IV SD Gugus Larasati belum mencapai kriteria ketuntasan minimal, hal ini disebabkan siswa mengalami kesulitan dalam menyelesaikan soal cerita. Model yang digunakan cenderung berpusat pada guru.Penelitian ini bertujuan untuk menguji keefektifan model Problem Based Learningberbantuan media tangram terhadap hasil belajar matematika siswa. Penelitian ini menggunakan metode kuantitatif dan jenis penelitian quasi eksperimen dengan desain nonequivalent control group design. Teknik sampel yang digunakan adalah cluster random sampling yaitu pengambilan sampel secara acak. Pengumpulan data penelitian menggunakan tes, observasi dan dokumentasi. Hasil penelitian menunjukkan bahwa hasil belajar siswa kelas eksperimen lebih tinggi dari KKM; hasil belajar siswa kelas eksperimen lebih baik dari kelas kontrol dengan nilai. Rata-rata n-gain kelas eksperimen masuk kategori sedang dan rata-rata n-gain kelas kontro masuk kategorirendah.Berdasarkan hasil penelitian dapat disimpulkan bahwa penerapan model PBL berbantuan media tangram efektif terhadap hasil belajar matematika kelas IV SD Gugus Larasati.
\end{abstract}

Kata kunci:hasil belajar matematika, model Problem Based Learning (PBL), tangram.

\section{ABSTRACT}

Based on the results of observations and interviews cognitive learning outcomes of mathematics of grade 4 th elementary school students at Larasati Cluster had not reached the minimum completeness criteria because students have difficulty in solving story problems. The model usedis teacher-centered. This study aimed to test the effectiveness of the Problem Based Learning model assisted by tangram media towards students' mathematics learning outcomes. This study used quantitative method and the type of experimental research was quasi experimental with non-equivalent control group design. The sampling technique used was cluster random sampling. The data instruments were tests, observation and documentation. The results of the study test showed that the experimental class student learning outcomes were higher than minimum criteria;student learning outcomes of the experimental class are better than the control class. The average of n-gain in the experimental class was moderate and the control class was low. Based on the results of the study it can be concluded that the application of the PBL model assisted by tangram was effective towards the mathematics learning outcomes of the 4 thgradestudents elementary schoolsin Larasti Cluster.

Keywords: mathematics learning outcomes, Problem Based Learning (PBL) model, tangram.

How to Cite: Trimurtini\& Laela, Nur. (2020). Keefektifan Model Problem Based Learning Berbantuan Tangram terhadap Hasil Belajar Matematika Siswa Kelas IV. Journal of Medives: Journal of Mathematics Education IKIP Veteran Semarang, 4(2), 375-383. 


\section{PENDAHULUAN}

Peraturan Pemerintah Republik Indonesia 32 Tahun 2013 bahwa proses pembelajaran di sekolah dasar hendaknya menantang, menyenangkan, interak-tif, sehingga siswa mampu mengem-bangkan kreativitasnya dan kemandirian sesuai bakat, minat, dan perkembangan fisik maupun psikologisnya. Berdasar-kan Permendikbud tersebut, siswa harus berpartisipasi secara aktif, kreatif dan inovatif dalam proses pembelajaran matematika. Siswa dibimbing guru untuk mengembangkan kemampuan berpikirnya dan kreativitasnya dalam memecahkan suatu masalah sehingga guru harus dapat mengembangkan model pembelajaran yang inovatif dan kreatif.

Berdasarkan kegiatan observasi dan wawancara yang peneliti lakukan di kelas IV SD Gugus Larasati Semarang yang meliputi SDN Pakintelan 01, SDN Pakintelan02, SDN Pakintelan 03, SDN Plalangan 02, SDN Plalangan 04, dan SDN Sumurrejo 02, terdapat beberapa masalah di Gugus Larasati tersebut. Masalah yang ditemui peneliti antara lain penggunaan model pembelajaran yang belum optimal, mengalami kesulitan dalam menyelesaikan soal berbentuk soal cerita, pembelajaran yang kurang menantang, akitivitas siswa dalam pembelajaran terlihat pasif karena tidak pembentukan kelompok kerja/tim untuk berdiskusi mengenai suatu masalah, media danalat peraga matematikayang mendukung pembelajaran di sekolah kurang memadai. Hal tersebut diperkuat dengan hasil wawancara guru kelas dan data hasil belajar matematika siswa kelas IV. Dari data diperoleh hasil belajar matematika di SD Gugus Larasati Semarang masih rendah.Dilihat dari Ketuntasan Kriteria Minimal (KKM) dari 144 siswa kelas IV di SD Gugus Larasati sebanyak 29 anak (27\%) nilainya di atas KKM dan 105 anak (73\%) nilainya masih di bawah KKM.Dari permasalahan tersebut, perlu adanya inovasi model pembelajaran dengan menerapkan model pembelajaran yang efektif dan kreatif dalam merangsang pemikiran siswa sehingga dapat meningkatkan hasil belajar siswa.

Model PBL(Problem Based Laerning) mendorong siswa bekerja dengan berbagai bahan dan alat, sebagian diantaranya tersedia di kelas, lainnya di perpustakaan atau laboratorium komputer (Rusmono,2017). Menurut Karyoto (2015) dalam model Problem Based Learning peran guru adalah sebagai fasilitator dengan menyediakan bahan dan alat untuk membantu siswa dalam menangani masalah.Penanganan masalah sepenuhnya diserahkan kepada siswa. Tujuannya adalah agar siswa berusaha belajarmenangani permasalahan yang ada. Proses belajar mengajaragar dapat berhasil dengan baik, siswa sebaiknya diajak untuk memanfaatkan alat inderanya, guru berupaya untuk menampilkan rangsangan atau stimulus yangdapat diproses dengan berbagai alat indera melalui media.Pada kerucut pengalaman Dale(dalam Arsyad:2014) bahwa semakin tinggi letak jenis media dalam tingkat kerucut semakin tinggi tingkat keabstrakannya. Arsyad (2014:14) mengemukakan bahwa penafsiran pesan 
melibatkan indera penglihatan maupun pendengaran, meskipun partisipasi fisik berkurang, keterlibatan imajinatif semakin bertambah dan berkembang.

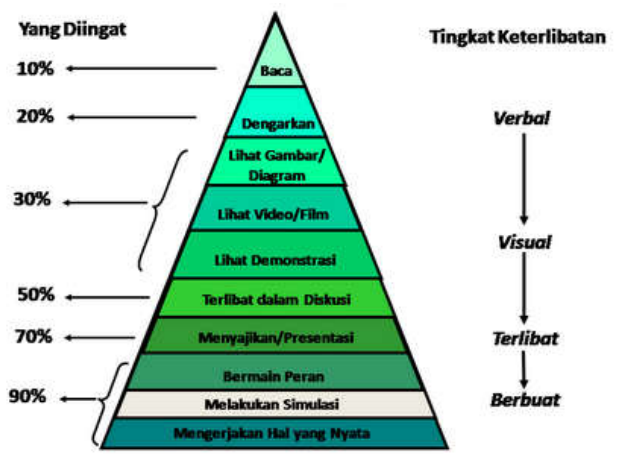

Gambar 1. Kerucut Pengalaman Edgar Dale

Dalam pembelajaran geometri 2 dimensi, utamanya bagi siswa SD diperlukan media yang sesuai. Dari Penelitian sebelumnya media tangram dapat membantu siswa dalam memahami materi geometri bangun datar (Trimurtini, Sari, \& Ahmadi, 2018).Menurut Sundayana (2018:64) tangram adalah suatu permainan yang sudah dikenal di seluruh dunia ditemukan di China, bagian tangram yang menarik yakni adanya bentukbentuk dasar geometri datar. Sejalan dengan pendapat Schiro (2009:215) bahwa dari bentuk-bentuk geometri yang berbeda-beda dapat dibentuk menjadi bentuk geometri yang lain, proses menggabungkan bentuk geometri ini dapat membantu anak mengembangkan kemampuan mereka untuk bekerja pada tingkat intuitif. Menurut Siew (2013) penggunaan permainan tangram dalam pembelajaran geometri di sekolah dasar sangat berpengaruh dalam berpikir geometri siswa untuk memahami konsep geometri Van Hiele. Kegunaan tangram ini adalah untuk menumbuhkan daya kreativitas siswa dalam membentuk bangun, dan untuk pemahaman kekekalan luas. Dengan menggunakan media tangram pada muatan pelajaran matematika dapat disajikan dengan jelas dan bermakna karena media tangram ini berbentuk konkret dan memiliki ukuran yang tetap, selain itu tangram dapat dimainkan oleh siswa sehingga siswa memiliki pengalaman baru yang diperoleh untuk membangun pengetahuannya untuk lebih memantapkan pemahaman konsep mengenai konsep bangun datar dan menumbuhkan kreativitas siswa dalam membentuk bangun-bangun tertentu.

Penelitian sebelumnya yang mendukung model PBL oleh Asriningtyas, Firosalia Kristin,dan Indri Anugraheni (2018) menunjukan bahwa dengan menerapan model pembelajaran PBL (Problem Based Learning) dalampenyelesaikan soal cerita pada mata pelajaran matematika kelas IV SD Negeri Suruh 01 kemampuan berpikir kritis siswa dapat ditingkatkan. Penelitian yang dilakukanoleh Agustin (2013:89)dengan judul "Peningkatan Aktivitas dan Hasil Belajar Siswa MelaluiModel Problem Based Learning (PBL)" yang dilakukan untukmeningkatkan hasil dan aktivitas belajar siswa kelas IV serta performansi guru pada materi pecahan melalui model PBL di SD Negeri Wanareja Pemalang. Hasil penelitian menunjukkan bahwa model PBL dapat meningkatkan hasil belajar siswa, aktivitas belajar siswa, dan performansi guru dalam pembelajaran matematika materi pecahan di kelas IV 
SD Negeri 01 Wanarejan Pemalang. Peningkatan tersebut ditunjukkan oleh peningkatan hasil belajar siswa yaitu pada siklus I, nilai rata-rata hasil belajar siswa mencapai 68,14 dan persentase tuntas belajar 33 klasikal 70,59\%, sedangkan pada siklus II nilai rata-rata meningkat menjadi 84,31 dan persentase tuntas belajar klasikal menjadi $92,16 \%$.

Media tangram efektif digunakan dalam pembelajaran matematika menurut Puspasari, Zulkardi \&Somakin (2015), Apriliani (2014), Trimurtini \& Ahmadi (2017) karena selain dapat meningkatkan strategi menyelesaikan masalah siswa juga mendukung terlaksananya pembelajaran yang menyenangkan.

Tujuan penelitian ini adalah untuk menguji keefektifan model PBL berbantuan media tangram terhadap hasil belajar siswa kelas IV SD Gugus Larasati Kota Semarang.

\section{METODEPENELITIAN}

Metode yang digunakan dalam penelitian yaitu metode kuantitatif dengan desain penelitian nonequivalentcontrol group design.

Subjek penelitian adalah siswa kelas IV SDN Pakintelan 01 sebagai kelas eksperimen dan SDN Sumurrejo 02 sebagai kelas kontrol. Teknik pengambilan sampel yang digunakan yaitu cluster random sampling. Variabel bebas dalam penelitian yaitu model pembelajaranPBL berbantuan media tangramdan variabel terikatnya yaitu hasil belajar matematika. Teknik pengumpulan data menggunakan tes, observasi, dan dokumentasi. Teknik analisis data penelitian yaitu: teknik analisis data awal berupa uji normalitas dan homogenitas, teknik analisis data akhir berupa uji normalitas dan homogenitas, uji hipotesis (uji $z$, uji $t$, dan uji N-gain).

\section{HASIL DAN PEMBAHASAN \\ Uji Persyaratan}

Hasil uji persyaratan menunjukkan bahwa data pretes pada kelas kontrol dan kelas eksperimen berdistribusi normal dan homogen.Uji homogenitas juga dilakukan pada data posttest dan hasilnyadata posttest kelas kontrol dan kelas eksperimen mempunyai varians homogen.

\section{Uji Hipotesis}

Uji hipotesis digunakan ada 3 uji. Uji ketuntasan, uji t, dan uji n-gain.Uji ketuntasan (uji z) untuk mengetahui ketuntasan siswa.Uji ketuntasan hasil belajar bertujuan untuk mengetahui apakah hasil tes kelas eksperimen dan kontrol dapat mencapai KKM. Proporsi yang digunakan adalah $75 \%$ dengan KKM penelitian yaitu 70. Uji $\mathrm{z}$ ini menggunakan bantuan Microsoft Excel dengan taraf signifikansi 0,05. Berdasar-kan hasil perhitungan, pada kelas eksperimen diperoleh nilai $\mathrm{Z}_{\text {hitung }}=$ 0,909 dan $z_{\text {tabel }}=0,1736$ maka $\mathrm{H}_{0}$ ditolak karena nilai $Z_{\text {hitung }}>Z_{\text {tabel }}$. Sedangkan pada kelas kontrol diperoleh nilai $z_{\text {hitung }}=-1,7320$ dan $z_{\text {tabel }}=0,1736$ maka $\mathrm{H}_{0}$ diterima karena nilai $z_{\text {hitung }} \leq$ $\mathrm{Z}_{\text {tabel. }}$ Maka kelas eksperimen proporsi siswa yang tuntas belajar mencapai $75 \%$ karena $\mathrm{H}_{0}$ ditolak. Sedangkan kelas kontrol proporsi siswa yang tuntas 
belajar tidak mencapai $75 \%$ dan $\mathrm{H}_{0}$ diterima.

Selanjutnya uji $t$ untuk mengetahui perbedaan rata-rata antara kelas eksperi-men dan kelas kontrol. Uji $\mathrm{t}$ yang digunakan yaitu uji perbedaan rata-rata satu pihak adalah uji pihak kanan, peneliti menggunakan uji perbedaan rata-rata (uji t) satu pihak yaitu uji pihak kanan karena data berdistribusi normal dan homogen. Uji hipotesis mengguna-kan uji-t berbantuan Mircosoft Excel.Taraf signifikansi yang digunakan yaitu $\alpha=$ 0,05 . Kriteria pengujian yaitu apabila $t_{\text {hitung }}>t_{\text {tabel }}$ maka $\mathrm{H}_{0}$ ditolak. $\mathrm{T}_{\text {tabel }}$ dapat dilihat pada tabel. Berdasarkan hasil perhitungan, diperoleh $t_{\text {hitung }}=5,176$ dan $\mathrm{t}_{\text {tabel }}$ dengan $\alpha=0,05 \mathrm{dan} \mathrm{dk}=\mathrm{n}_{1}+$ $\mathrm{n}_{2}-2=24+25-2=47$ adalah 2,021 maka $t_{\text {hitung }}>t_{\text {tabel }}$ yang artinya $H_{1}$ diterima.Uji hipotesis $\mathrm{t}$ disajikan dalam Tabel 1.

Tabel 1. Hasil Uji t

\begin{tabular}{lcccc}
\hline \multicolumn{1}{c}{ Kelas } & N & $\begin{array}{c}\text { Rata- } \\
\text { Rata }\end{array}$ & $\mathbf{t}_{\text {hitung }}$ & $\mathbf{t}_{\text {tabel }}$ \\
\hline Eksperimen & 24 & 80,17 & 5,169 & 2,021 \\
Kontrol & 25 & 63 & & \\
\hline
\end{tabular}

Berdasarkan Tabel 1, nilai $t_{\text {hitung }}$ lebih besar daripada $t_{\text {tabel }}(5,169>$ 2,021), sehingga $\mathrm{H}_{0}$ ditolak berarti model pembelajaran PBL berbantuan media tangram lebih efektif daripada model pembelajaran DI berbantuan media gambar terhadap hasil belajar matema-tika kelas IV SD Gugus Larasati.

\section{Uji N-Gain}

Data keseluruhan peningkatan skor pretes dan postes siswa kelas IV
SD Gugus Larasati dalam pembelajaran matematika materi keliling dan luas bangun datar disajikan pada Gambar 2 .

Berdasarkan Gambar 2, skor peningkatan hasil pretest dan posttest, rata-rata pretest kelas eksperimen sebesar 40,33 dan rata-rata posttest meningkat menjadi 80,17. Hasil N-Gain sebesar 0,667 dengan kategori sedang. Rata-rata pretest kelas kontrol sebesar 47,16 dan rata-rata posttest meningkat menjadi 63. Hasil N-Gain kelas kontrol sebesar 0,299 dengan kriteria rendah. Jadi, N-Gain kelas yang menggunakan model PBL berbantuan media tangram pada kelas eksperimen lebih tinggi dibandingkan kelas kontrol. Hal ini menunjukkan bahwa siswa kelas eksperimen dengan model pembelajaranPBLberbantuan tangram mempunyai peningkatan hasil belajar lebih tinggi dibandingkan siswa kelas kontrol dengan model DI berdasarkan nilai pretest dan posttest yang didapat.

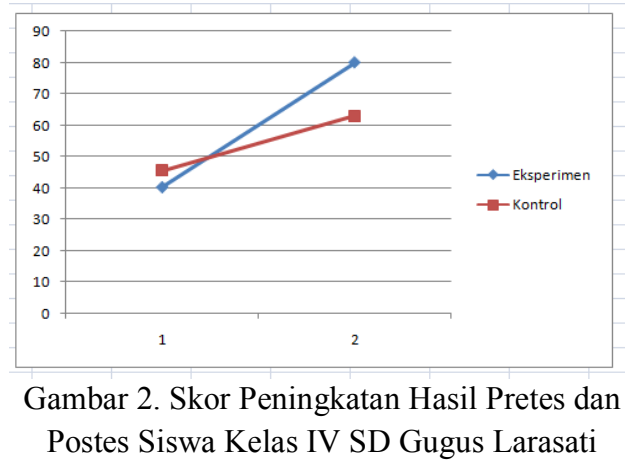

\section{Pembahasan}

Proses pembelajaran di kelas eksperimen model yang digunakan adalah model PBL berbantuan media tangram pada proses pembelajaran muatan pelajaran matematika pada materi keliling dan luas bangun datar 
persegi, persegi panjang, dan segitiga. Pertemuan dilakukan 4 kali pertemuan dengan alokasi waktu 2 jam pelajaran (2 $\times 35$ menit) setiap pertemuannya. Pada pertemuan ke-1 materinya keliling persegi dan persegi panjang. Pada pertemuan ke-2 materinya luas persegi dan persegi panjang. Pada pertemuan ke-3 materinya keliling dan luas segitiga dan pada pertemuan ke-4 materinya keliling dan luas gabungan. Pada proses pembelajaran matematika menggunakan sintak model PBL berbantuan media tangram. Tahapan pada model ini meliputi mengamati dan mengorientasikan siswa kepada masalah, dengan cara kegiatan pengamatan terhadap masalah (kartu masalah). Pada model PBL, masalah yang diajukan oleh guru adalah permasalahan dunia nyata.Siswa selanjutnya dapat menanya dan memunculkan masalah. Setelah siswa mencermati masalah dan menggali apa saja yang diketahui dalam permasalahan selanjut-nya siswa mencoba menemukan atau memunculkan masalah apa yang akan dicari penyelesaiannya dalam permasa-lahan tersebut dengan bantuan media tangram sehingga muncul suatupertanyaan. Siswa secara berkelompok berdiskusi mengumpulkan informasi sebanyakbanyaknya untuk mencari penyelesaian dari permasalahan tersebut dengan mencari dari berbagai sumber. Menurut Purnomo (2015:111) Dengan serangkaian masalah yang dikerjakan secara individu dan kelompok tersebut, siswa dapat saling membantu untuk mendapatkanpengetahuan yangbaru danmeningkatkan kemampuan pemecahan masalah. Salah satunya dengan menggunakan media tangram sebagai media untuk mengumpulkan informasi terkait penyelesaian permasalahan dengan pengamatan penyelidikansecarabersama-samadalam kelompok sampai menemukan pemecahan, penggunaan media tangram ini sesuai dengan materi yang dipelajari siswaterkait keliling dan luas bangun datar persegi, persegi panjang, dan segitiga.

Dari hasil pengamatan siswa terlihat aktif dan antusias dalam mengerjakan LKPD (Lembar Kerja Peserta Didik), siswa terlihat antusias dan sangat aktif dalam mengajukan pertanyaan ke guru, siswa juga merasa tertantang ketika menyelesaikan suatu permasalahan dan berusaha menyelesaikan dengan waktu yang cepat. Menurut Susanto (2013:204) mengatakan bahwa dengan pembelajaran pemecahan masalah menghendaki siswa belajar aktif, bukannya guru yang lebih aktif dalam menyajikan materi pelajaran. Belajar aktif dapat menumbuhkan sikap kreatif. Sikap kreatif yang dimaksud adalah mencari sendiri, menemukan, merumuskan, atau menyimpulkan sendiri.

Penggunaan media tangram dalam PBL mampu membantu siswa dalam menyelesaikan masalah yang mereka hadapi di LKPD dengan percaya diri. Sejalan dengan pendapat Zulfatul Khoirina (2016:315) bahwa media tangram bermanfaat sebagai alat peraga guna membentuk pengertian akan ideide geometri dan mengembangkan kemampuan spasial. Siswa mengolah informasi yang telah dikumpukan dari tahap sebelumnya dan merumuskan jawaban pemecahan masalah sebagai 
solusi yang tepat untuk menjawab, dan Siswa secara berkelompok membagi tugas penyampaian hasil/laporan yang dilakukan melalui presentasi. Siswa melakukan presentasi untuk

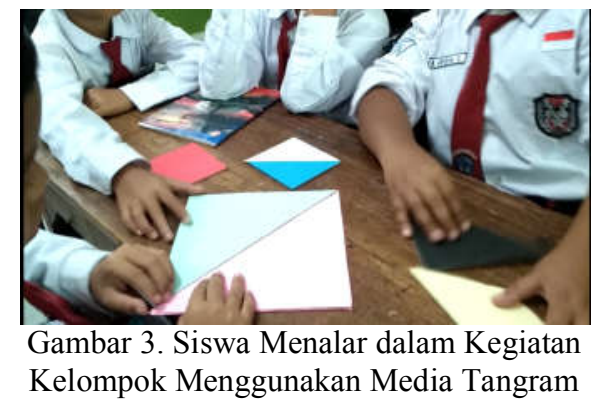

menyampaikan hasil diskusi.

Pembelajaran lebih bermakna dengan adanya media pembelajaran karena pesan yang terkandung dalam media lebih mudah ditangkap siswa dibandingkan siswa berfikir abstrak. Tingkatan pengalaman pemerolehan hasil belajar digambarkan oleh Dale (dalam Arsyad 2014:14) sebagai suatu proses komunikasi.Hal ini sejalan dengan pendapat Christina De Simone (2014:17) yang menyatakan bahwa "Good PBL problems are essential for learning; however, the type of learning derived from these problems is a function of PBL facilitators". Suatu masalah penting dalam suatu pembelajaran PBL, namun untuk masalah dalam pem-belajaran pada model ini sebaiknya sesuai dengan apa yang akan dipelajari dan berasal dari masalah sebagai fungsi dari fasilitator PBL. Permasalahan matematika terkait dengan materi keliling dan luas bangun datar persegi, persegi panjang, dan segitiga supaya kegiatan aktivitas yang dilakukan siswa dapat terarah danmenemukan suatu penyelesaian masalah dari beberapa siswa. Seperti yang dikatakan Ismail (2016:462) pembelajaran matematika dengan menggunakan alat bantu media tangram dapat meningkatkan aktivitas siswa dalam belajar. Kegiatan ini juga untuk mengumpulkan informasi dalam kelompok untuk menjawab penyelesaian masalah yang dihadapi. Dalam kelom-pok tersebut setiap siswa melakukan aktivitas mencari penyelesaian atau solusi alternatif didampingi guru dan siswa dalam kelompoknya. Pembelajar-an yang memberikan kesempatan siswa untuk belajar secara mandiri dalam kelompok dapat dikatakan pembelajaran yang efektif, hal ini sejalan dengan pendapat Hamalik (2014:171) pengajar-an yang efektif adalah pengajaran yang menyediakan kesempatan belajar sendiri atau melakukan aktivitas sendiri.

Pemahaman siswa pada kelas eksperimen ini cenderung lebih baik dari kelas kontrol dilihat dari hasil posttest siswa. Sependapat dengan Padmavathy (2013:45) model pembelajaran PBL memiliki pengaruh dalam pembelajaran dalam meningkatkan pemahaman siswa. Selain itu penggunaan media tangram pada pembelajaran matematika juga dapat meningkatkan prestasi belajar siswa (Utami 2016: 266) .

Temuan menarik dari hasil penelitian ini adalah siswa mulai belajar bernalar untuk menemukan dan memecahkan masalah dalam materi geometri datar yaitu keliling dan luas daerah bangun datar dengan bantuan media tangram. Selain itu ukuran media 
tangram dapat disesuaikan untuk keperluan pembelajaran klasikal, kelompok maupun individual.Sehingga model PBL menjadi efektif karena tidak hanya meningkatkan hasilbelajar siswa tetapi mengaktifkan siswa secaraindividu maupun kelompok.

\section{PENUTUP}

Berdasarkan hasil penelitian dan pembahasan dapat disimpulkan bahwa model pembelajaranPBL berbantuan media tangram efektif digunakan pada muatan pelajaran matematika materi keliling dan luas bangun datar kelas IV SD Gugus Larasati, Kota Semarang. Hal tersebut dibuktikan dengan rata-rata postes kelas eksperimen lebih tinggi daripada kelas kontrol, rata-rata postes kelas eksperimen sebesar 80,17 dan rata-rata posttest kelas kontrol sebesar 63. Hasil uji-t menunjukkan bahwa nilai $t_{\text {hitunglebih besar daripada }} t_{\text {tabel }}(5,179>$ 2,011)sehingga dapat disimpulkan hasil belajar siswa dengan menggunakan model pembelajaran PBL lebih tinggi dibandingkan dengan model pembelajar-anDI. Rata-rata n-gainkelas kontrol ku-rang daripada kelas eksperimen $\quad(0,299<0,667)$,sehingga kelas eksperimen memiliki perubahan lebih tinggi (antara nilai pretest dan posttest) dibandingkan dengan kelas kontrol.

\section{DAFTAR PUSTAKA}

Agustin, V.N. (2013). Peningkatan Aktivitas dan Hasil belajar siswa melalui Model PBLJournal of Elementary Education. 2(1):36.

Apriliani ,T.S. (2014). Peningkatan Aktivitas Dan Hasil Belajar
Matematika Melalui Tangram Dengan Penerapan Model PAIKEM. Journal Of Elementary Education. 2(2):38

Arsyad, Azhar. 2014. Media Pembelajaran. Jakarta: PT.Rajagrafindo Persada

Asriningtyas, Kristin F., Anugraheni I. (2018). Penerapan Pembelajaran $P B L$ untuk meningkatkan kemampuan berpikir dan hasil belajar matematika siswa kelas 4 SD. Jurnal Ilmiah Pendidikan Matematika, 3(1):23-32

Hamalik, Oemar. (2014). Proses Belajar Mengajar. Jakarta: PT. Bumi Aksara.

Ismail. (2016). Manajemen Pembelajaran Matematika Menggunakan Media Tangram Pada Siswa SD di Kepahiang. Manager Pendidikan,10(5):455463.

Karyoto. (2015). Keefektifan $P B L$ untuk meningkatkan kemampuan kritis matematik siswa sekolah dasar.Jurnal Tunas Bangsa, 1(2):76.

Khoirina , Zulfatul.(2016). Pengaruh Media Tangram Terhadap Hasil Belajar Tema Lingkungan Siswa Kelas III Madrasah Ibtidaiyah Da'watul Khoir Nganjuk. JPGSD. 4(2): 315.

Peraturan Pemerintah Republik Indonesia No. 32Tahun 2013 tentang Standar Nasional Pendidikan.

Permendikbud Nomor 22 tahun 2016 tentang Standar Proses Pendidikan Dasar dan Menengah.

Purnomo,D J., AsikinM,\&Rahmawati I Junaedi. (2015). Tingkat Berpikir KreatifPada Geometri Siswa 
Kelas Vii Ditinjau Dari Gaya Kognitif Dalam Setting Problem Based Learning. Unnes Journal of Mathematics Education.4(2):110115.

Puspasari, L, Zulkardi, \& Somakin. (2015). Desain Pembelajaran Luas Segi Banyak Menggunakan Tangram Berpetak Di Kelas IV.Jurnal Inovasi Pembelajaran. 1(2):161.

Rusmono. (2017). Strategi Pembelajaran Dengan Problem Based Learning Itu Perlu. Jakarta: Ghalia Indonesia.

Schiro, Michael S. (2009). Mega-Fun Math Games and Puzzles For The Elementary Grades. San Fransisco:Jossey - Bass.

Siew, N.M., Chin L.C, Mohamad R.A. (2013). Facilitating Students's Geometric Thinking Through Van Hieles's Phase-Based Learning Using Tangram.Journal of Social Sciences. 9(3) : 1.

Sugiyono. (2016). Metode Penelitian Pendidikan. Bandung: Alfabeta.

Simone, Christina De. (2014). ProblemBased Learning in Teacher Education: Trajectories of Change. International Journal of Humanities and Social Science, 2(1):17-29.

Sundayana, Rostina. (2018). Media dan Alat Peraga Pembelajaran Matematika. Bandung: Alfabeta.

Susanto, Achmad. (2016). Teori Belajar dan Pembelajaran di Sekolah Dasar. Jakarta: Kencana.

Trimurtini \& Ahmadi, Farid. (2017). Tangram Interactive Game (TIG): Instructionalmedia In Learning Geometry. Proceeding $3 r d$ International Conference on
Theory and Practice (ICTP-2017) Adelaide, South Australia.

Trimurtini, Sari, E. F., \& Ahmadi, F. (2018). Primary School Teachers ' $\mathrm{C}$ apability in Developing Learning Media Basedon Tangram Interactive Game. 5th International Conference on Community Development (AMCA 2018), 231(Amca), 519-521.

Utami, R.A. (2016). Peningkatan Prestasi Belajar Matematika Siswa Kelas III Melalui Media Tangram. Jurnal Pendidikan Guru Sekolah Dasar. 13(1): 266 